\title{
The Influencing Factors for A Pregnant Mother give Birth with Traditional Birth Attendant (A Case Study in. Bangko District, Rokan Hilir Regency, Riau)
}

\author{
Wan Sri Widaningsih and Nurman Achmad \\ Departemen Sosiologi, Universitas Sumatera Utara \\ Wansri44@gmail.com
}

Key Words: The Influencing factors for a pregnant Mother, Give Birth, Traditional Birth Attendant.

\begin{abstract}
This study discusses the existence of traditional birth attendant services in the district. Bangko till now. The purpose of this study was to describe the factors that influence pregnant women to give birth by using traditional birth attendants and also services provided by traditional birth attendants to pregnant women. This research is a descriptive type with a qualitative approach. The methods used in data collection were participatory observation and interviews, with informants, namely mothers who had given birth to traditional birth attendant and traditional birth attendant themselves. The results of the study are the factors that influence pregnant women who give birth with traditional birth attendants, namely the existence of hereditary habits, beliefs, social relations between patients and traditional birth attendants, social and economic conditions and background of mothers who give birth at a traditional birth attendant, more services for the traditional birth attendant. plenary, far health service distance with difficult transportation, and fear of using medical equipment. While the care provided by the traditional birth attendant includes examination of the patient's womb, the delivery process, and post-delivery services.
\end{abstract}

\section{INTRODUCTION}

Today, we recognize two systems of medicine, both of which provide the best service for their patients. It is not uncommon for patients to sometimes find it difficult to determine what type of treatment is good to cure their disease. All types of medicine are modern medicine that uses professional medical personnel and traditional medicine. This type of traditional medicine is also commonly believed by the community because the knowledge has been passed down from generation to generation or is usually acquired by someone as an advantage.

The traditional medicine system has received a lot of attention from the public because this system is still living and side by side with the modern medical system, even though biomedical medical practices are growing rapidly in our country which is marked by the emergence of health service centers, both managed by the government and by the private sector. Traditional medicine is closely related to the culture of an ethnic group inhabiting a certain geographical area. This traditional medicine is also commonly used in overcoming various health problems both in villages and in big cities.

Traditional medicine is treatment and treatment by means of medicine and treatment, which refers to the experience and skills passed down from generation to generation and is applied in accordance with the norms prevailing in society. Traditional medicine is an ingredient or ingredient in the form of plant material, animal material, mineral substance or a mixture of these ingredients from generation to generation that has been used for treatment based on experience.

Whereas in the 19th century since modern medicine developed with the discoveries of bacteria and the invention of the microscope, experts began to conclude that the disease had a cause. Modern medicine is widely adopted because it is based on the treatment of disease through the process of diagnosis and is assisted by tools such as microscopes, X-rays, surgical instruments, etc. to detect the cause of the disease before being given the medicine or being cured. However, modern medicine is not able to deal with all health problems, 
only about $20 \%$ of diseases that can be treated through modern medicine, the rest is unknown.

The basic difference between modern medicine and traditional medicine is that modern medicine considers humans to be more materialistic (blood, bones, flesh, and neglects the spiritual aspects of man) and uses materialistic medicines and increasingly sophisticated tools to diagnose the disease of its patients.

However, the modern medical system had experienced rejection from the community due to the principles of the modern medical system which did not match the understanding of those who generally live in rural areas. Even though they can accept it, not in its entirety but there is still a role for external elements which they still believe in (Hasim Awang, 1990).

Health problems are the consequences of behavior in the form of conscious or unconscious actions, detrimental to health or to reduce the health status of the perpetrator himself, or other people, or a group. According to Foster and Anderson (1978), in rural society the concept of disease is known as the personalistic system and the naturalistic system. The personalistic system is a disease that is believed to be caused by something outside the sick person, such as a result of someone's magical interference (witchcraft), jinn, spirits, curses, etc. Naturalistic system is a disease caused by natural causes such as weather and disturbances in body balance.

In the concept of illness, there are social, psychological and cultural factors that influence it. Some of these factors are: (1) Not all social or cultural groups react the same to disease; (2) Cultural background influences the way a person deals with the illness he experiences and also the diseases experienced by others; and (3) How cultural factors also affect a person in reducing the pain they experience to people who can heal or are healthrelated (Cecil G. Helman, 1994).

The understanding of the disease affects the pattern of treatment and the choice of treatment alternatives. At least the concept of traditional medicine which has a cosmological view of disease views disease not only at what causes pain, but how and why a person gets sick. Pain is the result of a series of relationships between individuals and their environment, in which the individual is an inseparable part of a cosmic order (Yitno, 1985).

Not only in terms of curing diseases, traditional medicine systems are also widely used in the care and delivery of pregnant women. The existence of a traditional birth attendant or the so-called traditional birth attendant creates an option for pregnant women to choose between a medical midwife and a traditional birth attendant.
The number of pregnant women who often ask the traditional birth attendant for services is a phenomenon which shows that the traditional birth attendant still has a place in the hearts of pregnant women who entrust their womb and delivery process to the traditional birth attendant. In fact, traditional birth attendant are not equipped with knowledge from the medical world regarding health standards that must be provided to their patients. But with the knowledge passed on by their parents and the experiences that accompany it, the traditional birth attendant can still be trusted by some mothers. Usually this phenomenon occurs in areas far from cities and health service providers.

One of the areas referred to is Bangko District, Rokan Hilir Regency, Riau. The description of the examination and delivery habits of pregnant women there is not much different from pregnant women in various other small areas. Most of these pregnant women in the process of pregnancy have a habit of examining their wombs with health workers. Starting from the first trimester, the number of pregnant women who visited to have their uterus checked was quite large. However, nearing the time of their baby's birth, pregnant women in this area begin to rarely return to health workers just to find out about their baby's development or entrust the process of giving birth to the medical personnel. It turns out that these pregnant women prefer traditional birth attendants to handle the childbirth process.

It is not impossible that the birth carried out by the traditional birth attendant can endanger the lives of the mother and the baby, because the traditional birth attendant usually does not meet established health standards in practice. The threat of maternal and infant mortality is even greater because the traditional birth attendant only works alone and uses minimal tools.

That justifies the results of research conducted by the Women's Research Institute (WRI) during 2007 in seven districts in Indonesia shows, until now some women from poor families still choose to use the services of herbalists / babies to help the process of childbirth. Free health insurance does not necessarily reduce the choice of poor women to go to the shaman. This is still the case in some areas. WRI research conducted North Lampung (Lampung), Lebak (Banten), Indramayu (West Java), Solo (Central Java), Jembrana (Bali), Central Lombok (West Nusa Tenggara), and West Sumba (East Nusa Tenggara), it was influenced by many factors. (Antara News, 2008).

Meanwhile, tempo efisiensi news, in 2010, the number of babies in Probolinggo regency whose birth process is handled by baby shamans is still quite high. In the past year it reached 1,226 
childbirths. Of these, ten died. According to the health office of Probolinggo Regency, the role of baby shamans is unlikely to be immediately eliminated because of the cultural influence of many people who believe in baby shamans (Tempo, 2010).

Even a study in an area in Surabaya in 2011 still found a history of childbirth that was not helped by nakes (Ni'ana, 2011). There is a suspicion that the aid was done by a baby shaman because by chance the research site was inhabited by a certain ethnicity.

In fact, the government has banned the birth process assisted by traditional birth attendants. The 2003 National Policy does not legalize traditional birth attendant anymore. The TBA can only handle the care of the baby and the mother, while the delivery process is left to the midwife. This is because, although it has been trained, there are still many practices of baby shamans that are contrary to health (Khasanah, 2011). But actually not all baby shamans are shunned by the community, some research of baby shamans that have been done turns out that the role of baby shamans is not only limited to childbirth assistance but also covers various other aspects, such as washing clothes after the mother gives birth, bathing the baby during the umbilical cord has not puput (loose), massage the mother after childbirth, bathe the mother, wash the mother's hair after 40 days of childbirth, perform alms ceremonies to the supra-natural nature, and can provide tranquility to her patients because all her actions are connected with the supra-natural nature that according to people's beliefs will affect human life (Anggorodi, 2004). Baby shamans are mostly wellknown people in the village, regarded as trustworthy parents and have a huge influence on the families they help (Anggorodi, 2009).

Apart from all that, with the large number of pregnant women giving birth with traditional birth attendants and the availability of sufficient infrastructure, researchers are interested in conducting this research to find out what is the reason for pregnant women choosing a traditional birth attendant as a place of delivery and how the TBA's care for pregnant women.

\section{RESEARCH METHOD}

This type of research used by researchers is descriptive research with a qualitative approach. The qualitative approach is intended to understand the phenomenon of what the research subject is experiencing in a holistic (whole) manner. Descriptive research aims to describe in detail a social phenomenon as a whole in analyzing people's behavior starting from the institutional scale of the family or group or community and their interactions.
Descriptive also contains the work of taking notes, analyzing it, interpreting the conditions that occur.

Descriptive research with a qualitative approach will collect data in the form of words, pictures, and not numbers which may come from interview scripts, field notes, photos, videotapes, personal documents, notes or memos, other official documents (Moleong, 2005).

In this study, the informants were mothers who had given birth to a traditional birth attendant and traditional birth attendant themselves. And to get the informants needed, the researchers made observations in the environment around the researchers' residence during the research, especially the neighbors who were introduced to the researchers as mothers who had given birth with the help of a traditional birth attendant. Then the researchers conducted an interview about their reasons for choosing a traditional birth attendant and how the traditional birth attendant service system itself serves their patients, then an in-depth interview was conducted at the informant's residence.

In addition, data is also obtained indirectly through the object of research through documents, magazines, journals, and the internet that are considered relevant to the problem in this research.

\section{RESULT AND DISCUSSION}

There are some influencing factors for Pregnant mothers give birth with Traditional Birth Attendant, they are:

\section{Giving Birth with the Traditional Birth Attendant is a tradition}

When entering a fairly old pregnancy, pregnant women are usually drawn by their parents or in-laws to live there. The reasons vary, namely so that someone looks after the pregnant woman while her husband is working, some say that their parents' house is closer to the traditional birth attendant so that the traditional birth attendant can be sought for help as soon as possible, etc. Childbirth at a traditional birth attendant is usually recommended by their parents who also have the same habit of having the womb check and giving birth at the traditional birth attendant. Because this habit has been ingrained in their family, the traditional birth attendant is the main choice. the traditional birth attendant is also a regular member of the patient's family. So this element of family belief that has been passed down from generation to generation can also be used as a reason why pregnant women give birth with traditional birth attendants.

According to the informant Diah, that from her grandmother until she gave birth to her 11th child, she still used a traditional birth attendant and her parents told her to give birth only at a traditional 
birth attendant. In addition, according to the informant Feriyanti, she gave birth to a traditional birth attendant due to pressure from her in-laws, all of whom also gave birth at a traditional birth attendant, where the village midwife was experienced and well known by her in-laws. So it is clear that mothers who give birth to traditional birth attendant have a descent from the previous generation.

\section{Trust}

The relationship between the patient and the traditional birth attendant in the community is a relationship of trust, so without trust between the two treatments it is impossible to do well. So that patients will choose a midwife they can trust. Trust does not arise automatically; it takes time so that stories from the community about traditional birth attendant who are always successful in performing their duties are the main hope of patients to get success when they give birth.

According to the informant Rubiah, the traditional birth attendant can help if it is difficult to give birth, where when she is pregnant with a fifth child and it is difficult to give birth, the traditional birth attendant gives her dirty water (water soaked all the keys in her house) while reading a prayer, then not long after drinking the water, easier to give birth. The supranatual abilities that accompany the birth ability of the traditional birth attendant make the community believe that the traditional birth attendant can overcome various difficulties in their work.

\section{The Social Relationhip between the Patient and Traditional Birth Attendant}

The deep interaction between pregnant women and the traditional birth attendant makes them more intimate and there is trust between the two, which is usually created because they already know the village midwife. Usually the traditional birth attendant is the person closest to the community because the traditional birth attendant not only serves the patient during childbirth but also helps him or her bathe the baby and massage the patient's body until the specified time limit. Not infrequently, this interaction is also caused by their parents who already know the traditional birth attendant well.

According to informant Ismalinda, the traditional birth attendant is neither fussy nor old, in contrast to the impatient medical midwife. When he asked the traditional birth attendant many questions, he was also answered well. His family knew everything and he was also familiar with the traditional birth attendant.
4. Social and Economic Condition ad also education background of the mothers wgo give birth with Traditional Birth Attendant

According to BPS data from the results of the People's Welfare Indicator Survey, in 2005 the Rokan Hilir people's life expectancy index was 69.30. This number indicates that the population in Rokan Hilir Regency has not yet fully had a good level of welfare as measured by the life expectancy index. This means that they still need to get attention in the health sector in the form of health services, improving the quality and quantity of health facilities and infrastructure or reducing costs, which most of the people complain about.

This limited socio-economic condition is the main reason why the people of Rokan Hilir are more interested in a cheaper medical system and are not interested in down payments. So, this low socioeconomic condition makes it difficult for them to choose the traditional birth attendant. Besides that, the economic limitations in their families are due to the background of inadequate education. Most of the people of Rokan Hilir, especially mothers who give birth with a traditional birth attendant, are those who do not get enough education or they never go to school at all. As a result, the opportunity for them to think about the dangers of childbirth with a traditional birth attendant was not analyzed in too much detail.

From the description above, it can be said that the socio-economic conditions of mothers who give birth to a traditional birth attendant are those who fall into the poor category. For their daily living expenses, sometimes they still experience shortages, and the income is usually obtained only from their husbands. The income usually ranges from $\mathrm{Rp}$. 800,000 to Rp. $1,200,000$ per month with an average number of dependents above 3 people.

\section{Traditional Birth Attendant's Service is more complete}

With prices that are affordable to the community and free of advances and a more comprehensive service to a traditional birth attendant, people assume that the use of a traditional birth attendant is more profitable. Because the services provided by traditional birth attendant are not only limited to assisting the delivery process but also include bathing the baby and massaging it after delivery. Meanwhile, medical midwives only assist in the delivery process, without any post-delivery care.

\section{The distance to Paramedic is quite far, with difficult transportation access}

Another reason why medical midwives are rarely asked for their services by the community is because 
the distance between the residents' houses and the health center is very far, takes a long time, and travels through terrain that is very dangerous for the safety of pregnant women. Not to mention the difficult means of transportation. On average, they only have a bicycle and pedaling for an hour or more will feel very heavy for them. The only means of transportation are rickshaws, but of course it increases the amount of expenses when they want to have their contents checked by medical personnel.

A traditional birth attendant who is close to the community and usually lives close to where he lives is a better option. Not to mention that the traditional birth attendant's willingness to help them whenever needed can reduce anxiety. According to the informant Rini, she once had her womb checked by medical personnel on a bicycle by her husband. There are only pedicabs at the place and the cost is around 15 thousand. Meanwhile, the traditional birth attendant is close to his house and can be picked up at any time and is not worried about the costs.

So the construction of Integrated Health Service (Posyandu) or Public Health Center (Puskesmas) that is easily accessible by the community will help improve their health status.

\section{The fear from medical tools}

According to informant Agustina, she was afraid of needles and made her refuse to use a medical midwife. That's why he chose a traditional birth attendant, which if giving birth is rather difficult, only given the messy water. In the traditional birth attendant, only prayers are read to facilitate the birth and the prayers are read in a glass of water and then drunk to the patient.

Furthermore, there are several service systems at the Traditional birth attendant, namely:

\section{a. Patient's pregnancy check up}

Usually before giving birth, the patient first checks the womb at the traditional birth attendant he chooses. This examination aims to determine the location of the fetus whether it is problematic or not. In addition, patients can also predict when the birth will approach.

\section{b. Patient's giving birth Process}

Starting with a traditional birth attendant being picked up by the patient's relatives and being delivered directly to the patient's house, the traditional birth attendant immediately checks the patient's body condition, with the intention of being able to estimate whether the patient's condition is strong enough to give birth without any special assistance from him or vice versa.

If the patient's condition is weak, the traditional birth attendant advises the patient to eat half-cooked free-range chicken eggs to increase blood pressure and increase energy. But if the birth is difficult, the traditional birth attendant will use their knowledge in the form of supernatural knowledge beyond the capabilities of ordinary humans who are obtained as descendants of the traditional birth attendant family who are also a traditional birth attendant. A glass of plain water is read with various kinds of prayers that the traditional birth attendant believes can relieve the pain of his patient and make it easier for his patient to give birth. But before that the water in the glass had been soaked with various keys in the house which made childbirth easy.

When the baby is out, the baby's body is cleaned and the traditional birth attendant immediately asks the patient to push again to remove the uri-uri of the baby which is still in the patient's stomach. The traditional birth attendant also bathes the baby, if requested by the patient. The traditional birth attendant's next task is to clean the patient's limp body, replace the dirty clothes that are attached to his body and then perform a massage which is useful to relieve pain in the abdomen after childbirth. The massage is complete, followed by using an octopus (a kind of cloth to tie the patient's stomach). Then the traditional birth attendant returns to the back to wash the dirty cloth that she had soaked before.

\section{c. Post Partum Service}

The next morning, the traditional birth attendant was again picked up by the patient's family to treat the patient and see the patient's condition after giving birth. Arriving at the patient's house, the traditional birth attendant immediately bathes the baby and soaks the dirty cloth that the patient had used last night. Only then can the traditional birth attendant give a massage to the body, especially the patient's stomach, to reduce pain. the task continued until the third day after the patient gave birth.

On the last day of the traditional birth attendant's work, usually three days after giving birth, the traditional birth attendant is paid a wage in return for his services. According to the data obtained, each traditional birth attendant never negotiates the price before carrying out his duties. However, according to women who gave birth at a traditional birth attendant, the wages paid to the traditional birth attendant who served them were adjusted to the standard price paid by mothers who had previously given birth. This means that if most of the mothers pay the traditional birth attendant a fee of $\mathrm{Rp}$. 300,000 , then the other patients also pay that amount. The amount of wages the traditional birth attendant receives is also different if the patient gives birth to the first child or the second child and so on.

Referring to Weber's theory of rational action which states that giving birth to a traditional birth attendant to get healing and health safety is a rational action according to empirical thinking that 
someone gives birth to a traditional birth attendant to emphasize the purpose of birth safety and is associated with existing values in the community that giving birth at a medical midwife or hospital is very expensive.

If it is related to the Fukuyama theory that a person giving birth in a traditional birth attendant might bring great hope for safety and healing, and when someone gives birth in a traditional birth attendant because it is supported by the values of belief in the performance of a traditional birth attendant whose service is more complete at a relatively lower cost.

\section{CUNCLUSION}

The existence of traditional birth attendants in the district. Bangko is caused by the trust of pregnant women in TBA (Traditional Birth Attendant) services. In addition, the cost of hospitals and medical midwives is considered too expensive for people who need health services. The community's inability to pay for midwife services makes people reluctant to go to midwives. Traditional birth attendants offer services at low prices, which attract poor women. Then there is an emotional connection that is created between the TBA patients well. Because usually the use of the services of a TBA was previously used by the patient's parents or previous relatives. So that comes a sense of trust in people who already know the TBA well. This hereditary habit makes the TBA continue to exist in carrying out their work. Furthermore, access to a TBA is much easier than that of a midwife or others. Long distances, difficulty in transportation, locations that endanger patient safety, are also major considerations for patients to go to traditional healers. TBAs are believed to have supernatural abilities, so that they can facilitate the birth of babies. And this ability is believed only to be possessed by the TBA and not that of the midwife.

\section{REFERENCES}

Anggorodi R, Savitri M. (2004). Studi Kemitraan Bidan- Dukun di Kabupaten Kediri, Jawa Tengah dan Kabupaten Cirebon, Jawa Barat. Laporan akhir. Jakarta: Kerjasama FKM UI dengan $\mathrm{MNH}$.

Anggorodi, R. (2009). Dukun bayi dalam persalinan oleh masyarakat Indonesia. Makara Kesehatan, 13(1), 9-14.

Anderson, (1986). Health Anthropology. UI Press. Jakarta, Cetakan Pertama.

Antara News, Dukun Beranak Masih Jadi Pilihan Perempuan Keluarga Miskin. https://www.antaranews.com/berita/107512/dukunberanak-masih-jadi-pilihan-perempuan-keluargamiskin. Senin, 30 Juni 2008.23:32 WIB.

Awang, Hasim, A. R. 1990. Pengantar Antropologi Perubatan. Dewan Bahasa dan Pustaka. Kuala Lumpur Malaysia.

Helman, G. Cecil. 1994. Budaya Kesihatan dan Penyakit. Darul Ehsan Dewan Bahasa dan Pustaka. Selangor .

Khasanah, N. (2011). Dampak Persepsi Budaya terhadap Kesehatan Reproduksi Ibu dan Anak di Indonesia. Muwazah, [e-journal], 3(2), 487-492.

Moleong, Lexy, 1993. Metode Penelitian Kualitatif. Remaja Rosdakarya. Bandung.

Yitno, Amin. 1985. "Kosmologi dan Konsep Kesehatan pada Orang Jawa" dalam Soedarsono dkk. (Editor). Celaka, Sakit, Obat, dan Sehat Menurut Konsepsi Orang Jawa. Yogyakarta: Proyek Penelitian dan Pengkajian Kebudayaan Nusantara (Javanologi), Departeman Pendidikan dan Kebudayaan.

Ni'ana NR. 2011. Faktor yang Berhubungan dengan Pemberian ASI Eksklusif di Wilayah Puskesmas Sidotopo Wetan, Skripsi, Universitas Airlangga, Surabaya.

Tempo Interaktif. 2010. Seribu Kelahiran di Probolinggo Masih Ditangani Dukun Bayi http://www.tempo.co/read/news/2010/02/11/058 225179/1000-Kelahirandi-Probolinggo-MasihDitangani-Dukun-Bayi (13/Juli/2020) 